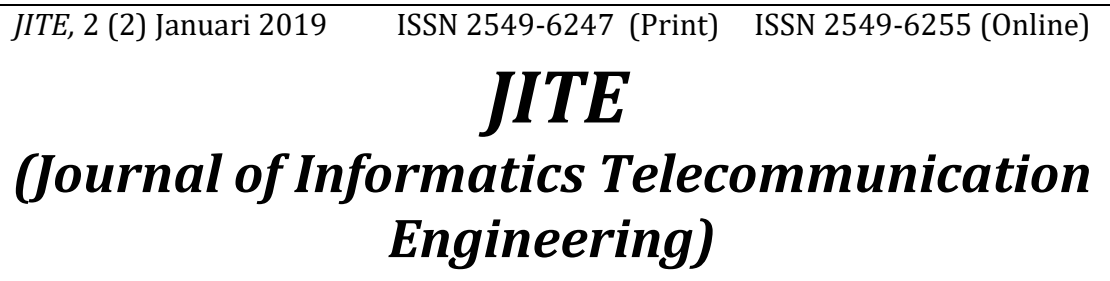

\title{
Sistem Pakar Penggunaan Jenis Ulos pada Acara Adat Batak dengan Metode Forward Chaining Berbasis Web
}

\section{Expert System for Using Ulos Types on Traditional Batak Events with the Web-Based Forward Chaining Method}

\author{
Yolanda Y.P Rumapea1)*, Margaretha Yohanna1) \\ 1) Universitas Methodist Indonesia, Indonesia \\ *Coresponding Email:rumapeayolanda@gmail.com
}

\begin{abstract}
Abstrak
Masyarakat batak adalah masyarakat adat. Dalam acara adat Batak tidak lepas dari yang namanya Ulos. Ulos adalah sebuah hasil karya yang telah memiliki makna yang tinggi serta mengandung makna ekonomi dan juga makna sosial. Banyak masyarakat Batak yang tinggal di kota kurang paham dalam acara adat Batak terutama pemilihan jenis ulos sehingga masyarakat memerlukan waktu yang lama dan hasil yang kurang efektik untuk mencari jenis ulos yang cocok digunakan pada kegiatan adat. Sistem pakar sangat berguna untuk memecahkan masalah yang rumit dan mengambil sebuah keputusan. Forward Chaining merupakan salah satu metode yang sering digunakan dalam sistem pakar, karena metode ini akan memulai pelacakannya dengan fakta-fakta yang ada dalam basis data. Melalui sistem pakar dengan metode forward chaining dapat memudahkan dalam mendeteksi jenis ulos yang cocok digunakan pada kegiatan adat tersebut, dan tentunya juga memerlukan proses identifikasi yang akurat untuk memberikan hasil keputusan yang tepat. Proses konsultasi berhasil dengan menampilkan jenis ulos yang digunakan dan juga solusi dan keterangan penggunaan ulos tersebut.
\end{abstract}

Kata Kunci: Metode Forward chaining, Sistem Pakar, ULos batak.

\begin{abstract}
Batak people are indigenous people. In the traditional Batak event, it cannot be separated from the name Ulos. Ulos is Ulos is a masterpiece that has a high meaning and contains economic meaning and social meaning. Many Batak people who live in the city do not understand the traditional ceremonies, especially the selection of ulos type so that the community needs a long time and ineffective results to find the type of ulos suitable for traditional activities. Expert systems are very useful for solving complex problems and making decisions. Forward Chaining is one method that is often used in expert systems, because this method will start tracking it with the facts in the database. Through an expert system, the Forward Chaining method can make it easier to detect the type of ulos that is suitable for the customary activities, and of course also requires an accurate identification process to provide the right decision results. The consultation process was successful by displaying the type of ulos used and also the solutions and information on the use of the ulos.
\end{abstract}

How to Cite: Rumapea, Y. Y., \& Yohanna, M. (2019). Sistem Pakar Penggunaan Jenis Ulos pada Acara Adat Batak dengan Metode Forward Chaining Berbasis Web. JITE (Journal of Informatics and Telecommunication Engineering). 2 (2):105-113 


\section{PENDAHULUAN}

Masyarakat batak adalah masyarakat adat. Adat diekspresikan lewat berbagai kegiatan adat secara individu maupun secara kolektif (C. Agustina, 2016). Acara adat selalu dilakukan masyarakat Batak baik masyarakat di desa maupun di kota. Dalam acara adat Batak tidak lepas dari yang namanya Ulos (Sri, 2015). Ulos adalah sebuah hasil karya yang telah memiliki makna yang tinggi serta mengandung makna ekonomi dan juga makna sosial (D.P. Fransiska, 2015). Oleh karena itu peredaran ulos ini tidak akan berjalan dengan sembarangan tanpa mempedomani makna dan nilai yang telah ditetapkan berdasarkan aturan dan norma-norma adat yang telah disepakati. Artinya "Ulos" sesuai dengan jenis dan maknanya akan diberikan dan diterima oleh orang yang tepat berdasarkan norma dan aturan-aturan yang telah ada dengan pedoman Falsafah adat Batak "Dalihan Natolu" (M.S. Destien \& H. Dasrun, 2015).

Banyak masyarakat Batak yang tinggal di kota kurang paham dalam acara adat Batak terutama pemilihan jenis ulos sehingga masyarakat Batak mengalami kesulitan dalam memilih jenis ulos yang akan mereka gunakan untuk acara adat tersebut.
Sistem pakar adalah sistem yang mengambil pengetahuan manusia ke dalam komputer yang dirancang untuk memodelkan kemampuan dalam menyelesaikan masalah seperti layaknya seorang pakar [3]. Dengan menggunakan sistem pakar, pemakai akan diajukan beberapa pertanyaan, kemudian pemakai memasukkan jawaban atau memilih jawaban yang ditampilkan dilayar komputer sehingga pemakai dapat menemukan rekomendasi atau output yang harus ditempuh pemakai berdasarkan jawaban yang dipilihnya (A. Zulfian,2011). Sistem pakar tersebut telah melacak solusi atau kesimpulan yang akan ditempuh oleh pemakainya. Pada saat ini sistem pakar sangat berguna untuk memecahkan masalah yang rumit dan mengambil sebuah keputusan (D. Muhammad, 2011).

Berdasarkan identifikasi masalah di atas, maka rumusan masalahnya adalah acara adat selalu dilakukan masyarakat Batak baik masyarakat di desa maupun di kota, sebagai contoh acara adat pernikahan, acara adat kematian, dan acara adat kelahiran.

Sistem pakar sangat berguna untuk memecahkan masalah yang rumit dan mengambil sebuah keputusan. 
Menurut Abram Gideon, et al(2015) Forward Chaining merupakan salah satu metode yang sering digunakan dalam sistem pakar, karena metode ini akan memulai pelacakannya dengan fakta-fakta yang ada dalam basis data.

Pada penelitian ini, sistem pakar diterapkan untuk mengambil keputusan pemilihan jenis beserta makna ulos dan dengan menggunakan pendekatan metode forward chaining. Batasan pada penelitian ini dapat diliat sebagai berikut:

1. Jenis ulos yang dibahas hanya untuk acara adat pernikahan, meninggal, tujuh bulanan, dan memasuki rumah baru.

2. Bahasa pemrograman menggunaka PHP dan perancangan database menggunakan mysql.

Tujuan penulisan penelitian ini adalah untuk merancang dan membangun sistem pakar penggunaan jenis ulos pada acara adat Batak agar masyarakat lebih mudah mendapatkan informasi mengenai jenis dan makna ulos Batak Toba yang sesuai dengan kebutuhan acara adatnya.

\section{METODE PENELITIAN}

\section{A. Analisa Sistem Pakar}

Diagnosis sendiri didefenisikan sebagai suatu proses penting pemberian nama dan pengklasifikasian ulos-ulos batak toba, yang menunjukkan kemungkinan kepada konsumen dan yang mengarahkan pada jenis ulos tertentu. Diagnosis banding, sebagaimana halnya dengan penelitian-penelitian ilmiah, didasarkan atas metode forward chaining. Dengan metode ini menjadikan ulos-ulos begitu mudah dikenali hanya dengan suatu kesimpulan diagnosis. Diagnosis banding dimulai sejak permulaan wawancara dan berlangsung selama melakukan pemeriksaan ke tempat penjualan ulos. Dari diagnosis banding tersebut akan diperoleh pertanyaan-pertanyaan yang terarah, perincian ciri-ciri ulos yang dilakukan untuk menentukan pilihan jenis ulos yang akan digunakan. Data yang berhasil dihimpun, akan dipertimbangkan dan diklasifikasikan berdasarkan permintaan dari konsumen.

\section{B. Representasi Pengetahuan}

Hal yang perlu diperhatikan untuk membuat representasikan pengetahuan berbentuk kaidah produksi untuk basis pengetahuan sistem pakar ini adalah pembuatan tabel keputusan (Decision Table) merupakan tabel yang digunakan sebagai alat bantu untuk menyelesaikan penyusunan logika di dalam program. Adapun bentuk 
keputusan yang dirancang untuk system pakar mengetahui jenis-

jenis ulos dapat dilihat pada Gambar 3 berikut ini:

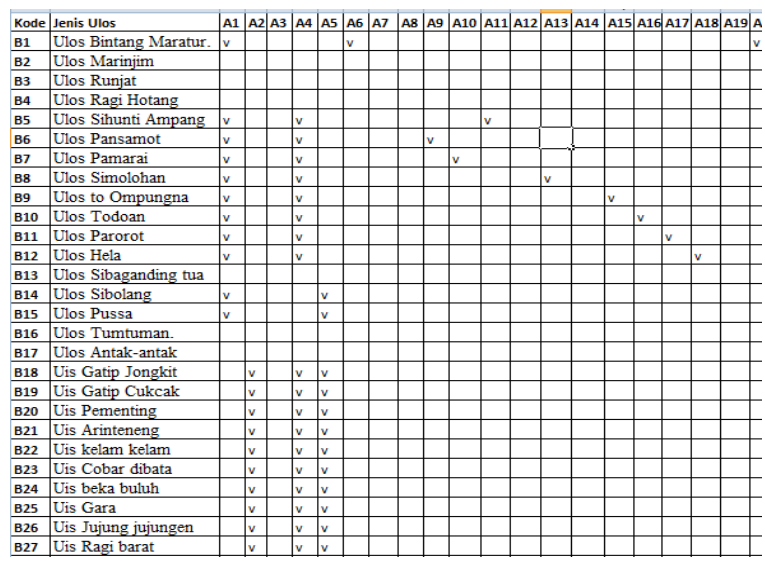

Gambar 1. Basis Aturan Ciri-Ciri Ulos

Tabel I digunakan untuk menentukan ciri- ciri ulos dari beberapa jenis ulos yang diketahui.

Tabel 1. Rule ulos

\begin{tabular}{|l|l|l|}
\hline RULE & IF & THEN \\
\hline 1 & $\mathrm{~A} 1$ & $\mathrm{~B} 1$ \\
\hline 2 & $\mathrm{~A} 2$ & $\mathrm{~B} 2$ \\
\hline 3 & $\mathrm{~A} 3$ & $\mathrm{~B} 3$ \\
\hline 4 & $\mathrm{~A} 4$ & $\mathrm{~B} 4$ \\
\hline 5 & $\mathrm{~A} 2, \mathrm{~A} 9$ & $\mathrm{~B} 5$ \\
\hline 6 & $\mathrm{~A} 2 \quad$ & $\mathrm{~B} 6$ \\
\hline 7 & $\mathrm{~A} 2, \quad \mathrm{~A} 3, \quad \mathrm{~A} 8$, & $\mathrm{B} 7$ \\
& $\mathrm{~A} 14, \mathrm{~A} 15$ & \\
\hline 8 & $\mathrm{~A} 2$ & $\mathrm{~B} 8$ \\
\hline 9 & $\mathrm{~A} 3$ & $\mathrm{~B} 9$ \\
\hline 10 & $\mathrm{~A} 3$ & $\mathrm{~B} 10$ \\
\hline 11 & $\mathrm{~A} 4$ & $\mathrm{~B} 11$ \\
\hline 12 & $\mathrm{~A} 4$ & $\mathrm{~B} 12$ \\
\hline 13 & $\mathrm{~A} 5$ & $\mathrm{~B} 13$ \\
\hline 14 & $\mathrm{~A} 5$ & $\mathrm{~B} 14$ \\
\hline 15 & $\mathrm{~A} 5$ & $\mathrm{~B} 15$ \\
\hline 16 & $\mathrm{~A} 6$ & $\mathrm{~B} 16$ \\
\hline 17 & $\mathrm{~A} 6$ & $\mathrm{~B} 17$ \\
\hline 18 & $\mathrm{~A} 6, \mathrm{~A} 9, \mathrm{~A} 12$, & $\mathrm{B} 18$ \\
\hline
\end{tabular}

\begin{tabular}{|c|c|c|}
\hline 19 & A6 & B19 \\
\hline 20 & A6 & $\mathrm{B} 2 \mathrm{O}$ \\
\hline 21 & $\mathrm{~A}_{7}$ & B21 \\
\hline 22 & $A_{7}$ & $\mathrm{~B} 22$ \\
\hline 23 & $\mathrm{~A}_{7}$ & $\mathrm{~B} 23$ \\
\hline 24 & $\mathrm{~A}_{7}$ & B24 \\
\hline 25 & $\mathrm{~A} 8, \mathrm{~B}_{14}$ & B25 \\
\hline 26 & A8 & B26 \\
\hline 27 & A9 & $\mathrm{B} 27$ \\
\hline 28 & A1o & $\mathrm{B} 28$ \\
\hline 29 & $\begin{array}{l}\mathrm{A}_{11}, \quad \mathrm{~A}_{12}, \\
\mathrm{~A}_{13},\end{array}$ & B29 \\
\hline 30 & $\mathrm{~A}_{11}, \mathrm{~A}_{14}, \mathrm{~A}_{16}$ & $\mathrm{~B}_{30}$ \\
\hline 31 & A18 & $\mathrm{B}_{31}$ \\
\hline 32 & A19 & $B_{32}$ \\
\hline 33 & $\mathrm{~A} 2 \mathrm{O}$ & B33 \\
\hline 34 & A21 & B34 \\
\hline
\end{tabular}

Keterangan pada Tabel I dapat dilihat pada tabel II.

Tabel 2. Keterangan Rule Ulos

\begin{tabular}{|c|c|}
\hline KODE & KETERANGAN \\
\hline A1 & Batak Toba \\
\hline $\mathrm{A} 2$ & Batak Karo \\
\hline $\mathrm{A}_{3}$ & Batak Simalungun \\
\hline $\mathrm{A}_{4}$ & Pernikahan \\
\hline $\mathrm{A}_{5}$ & Meninggal \\
\hline A6 & Tujuh Bulanan \\
\hline $\mathrm{A}_{7}$ & Baptisan \\
\hline A8 & Masuki Rumah Baru \\
\hline A9 & $\begin{array}{l}\text { Diberikan orang tua pengantin } \\
\text { perempuan kepada orang tua } \\
\text { pengantin laki-laki }\end{array}$ \\
\hline A10 & $\begin{array}{l}\text { diberikan oleh kakak atau adik laki- } \\
\text { laki dari ayah pengantin perempuan } \\
\text { kepada kakak atau adik laki-laki dari } \\
\text { ayah pengantin laki-laki. }\end{array}$ \\
\hline A11 & $\begin{array}{l}\text { diberikan oleh saudara perempuan } \\
\text { yang sudah menikah dari pengantin } \\
\text { perempuan kepada saudara } \\
\text { perempuan yang sudah menikah dari } \\
\text { pengantin laki-laki }\end{array}$ \\
\hline A12 & $\begin{array}{l}\text { diberikan oleh tante yang sudah } \\
\text { menikah dari pengantin perempuan } \\
\text { kepada tante yang sudah menikah } \\
\text { dari pengantin laki-laki }\end{array}$ \\
\hline
\end{tabular}




\begin{tabular}{|c|c|}
\hline A13 & $\begin{array}{l}\text { diberikan oleh saudara laki-laki yang } \\
\text { sudah menikah dari pengantin } \\
\text { perempuan kepada saudara laki-laki } \\
\text { yang sudah menikah dari pengantin } \\
\text { laki-laki }\end{array}$ \\
\hline A14 & $\begin{array}{l}\text { diberikan oleh om yang sudah } \\
\text { menikah dari pengantin perempuan } \\
\text { kepada om yang sudah menikah dari } \\
\text { pengantin laki-laki }\end{array}$ \\
\hline $\mathrm{A} 15$ & $\begin{array}{l}\text { diberikan oleh salah seorang } \\
\text { keturunan ayah/ ompung bersaudara } \\
\text { dari ayah pengantin perempuan } \\
\text { kepada salah seorang keturunan } \\
\text { ayah/ ompung bersaudara dari ayah } \\
\text { pengantin laki-laki. }\end{array}$ \\
\hline $\mathrm{A}_{31}$ & $\begin{array}{lll}\text { Untuk } & \text { menggendong } & \text { bayi } \\
\text { perempuan dan "abit" (sarung) laki- } \\
\text { laki }\end{array}$ \\
\hline $\mathrm{A}_{32}$ & $\begin{array}{l}\text { Untuk "gonje" (sarung) upacara adat } \\
\text { bagi laki-laki dan selimut bagi } \\
\text { "kalimbubu" (paman). }\end{array}$ \\
\hline A33 & $\begin{array}{l}\text { Kegunaannya sama dengan gatip } \\
\text { gewang, bedanya adalah gatip cukcak } \\
\text { ini tidak pakai benang emas. }\end{array}$ \\
\hline $\mathrm{A}_{34}$ & Untuk ikat pinggang bagi laki-laki \\
\hline$A_{35}$ & $\begin{array}{l}\text { Untuk tudung bagi anak gadis pada } \\
\text { pesta "guro- guro aron". }\end{array}$ \\
\hline A36 & $\begin{array}{l}\text { Sebagai alas waktu menjalankan mas } \\
\text { kawin dan alas piring tempat makan } \\
\text { pada waktu "mukul" (acara makan } \\
\text { pada saat memasuki pelaminan) }\end{array}$ \\
\hline A37 & $\begin{array}{l}\begin{array}{l}\text { Untuk tudung } \\
\text { "morang tua, untuk } \\
\text { laki) }\end{array} \\
\text { (kado untuk laki- }\end{array}$ \\
\hline $\mathrm{A}_{3} 8$ & $\begin{array}{l}\text { Untuk upacara kepercayaan, seperti } \\
\text { "uis jinujung", "berlangir" dan } \\
\text { "ngelandekken galuh" }\end{array}$ \\
\hline A39 & $\begin{array}{l}\text { Untuk "bulang-bulang" diikatkan di } \\
\text { kepala laki- laki pada upacara adat. }\end{array}$ \\
\hline $\mathrm{A}_{40} \mathrm{O}$ & $\begin{array}{l}\text { Untuk penggendong anak- anak, } \\
\text { tudung untuk orang tua dan anak } \\
\text { gadis }\end{array}$ \\
\hline $\mathrm{A}_{41}$ & $\begin{array}{l}\text { Untuk melapisi bagian atas tudung } \\
\text { bagi kaum wanita yang mengenakan } \\
\text { tudung dalam upacara adat }\end{array}$ \\
\hline
\end{tabular}

\section{Data Flow Diagram (DFD Konteks)}

Perancangan ini menggunakan diagram konteks, diagram ini menjelaskan tentang hubungan input/output antara sistem dengan dunia luarnya, suatu diagram konteks selalu mengandung satu proses saja yang mewakili proses seluruh sistem. Diagram konteks sistem dapat dilihat pada Gambar 4.

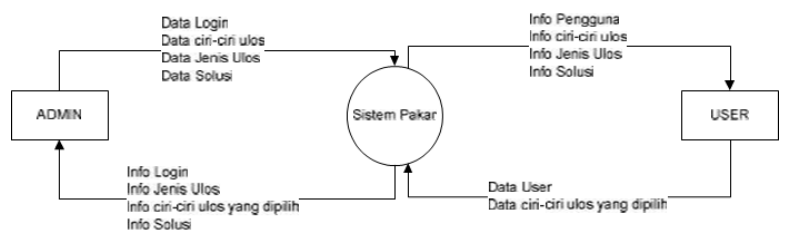

Gambar 4. Diagram Konteks

1. Data Flow Diagram (DFD) Level 1

Data Flow Diagram(DFD) Level 1 ini terdiri dari 5 proses. Data Flow Diagram (DFD) Level 1 dapat dilihat pada Gambar 5.

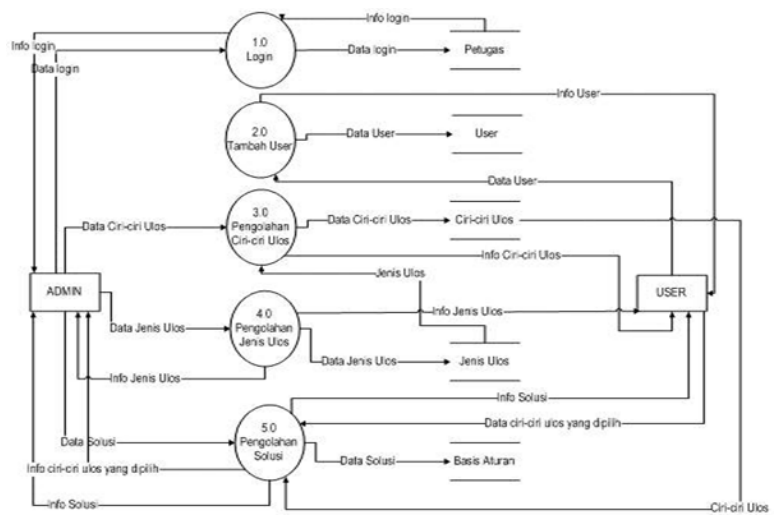

Gambar 5. Data Flow Diagram (DFD) Level 1

\section{Entity Relationship Diagram (ERD)}

ERD ini merupakan suatu model untuk menjelaskan hubungan antar tabel dalam basis data yang akan dibangun berdasarkan objek-objek dasar 
data yang mempunyai hubungan antar relasi. ERD ditampilkan pada Gambar 6.

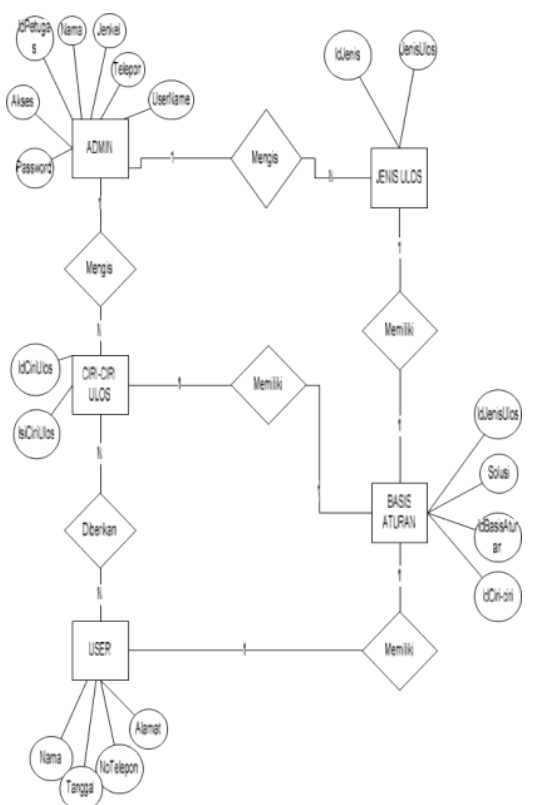

Gambar 6. Entity Relationship Diagram (ERD)

\section{HASIL DAN PEMBAHASAN}

\section{Tampilan Menu Login}

Gambar 7 adalah form yang berfungsi sebagai admin. Seorang admin yang ingin masuk harus diwajibkan memberikan username dan password yang benar. Apabila admin tidak memberikan data username dan password yang valid, maka admin tidak bisa masuk ke menu utama dan akan terdapat pemberitahuan bahwa username dan password yang diberikan tidak valid.

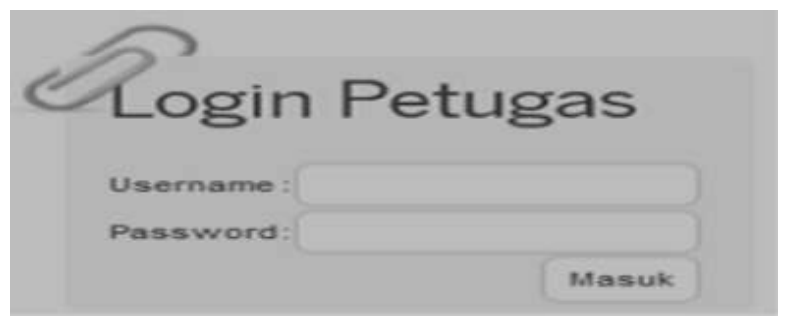

Gambar 7. Tampilan Menu Login

\section{Tampilan Input Petugas}

Gambar 8 merupakan tampilan gambar untuk input petugas. Untuk form penginputan data petugas, terdapat datadata yang wajib diisi oleh seorang admin, yaitu username dan password.

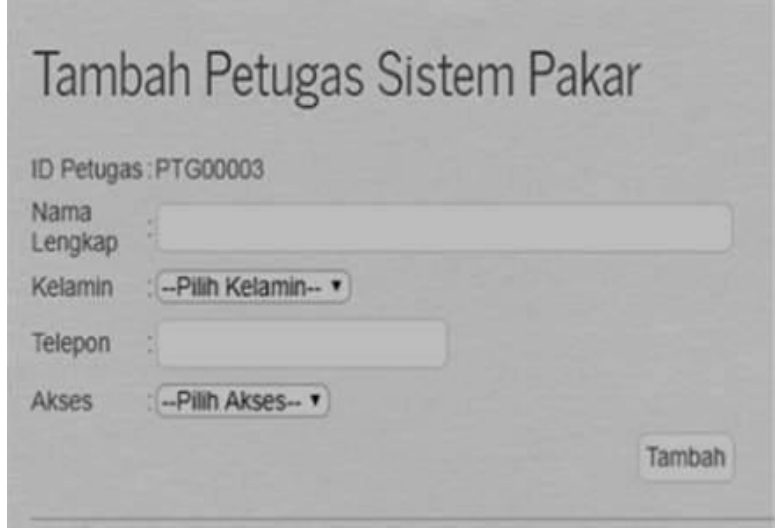

Gambar 8. Tampilan Input Petugas

3. Tampilan Input Ciri-ciri Ulos Batak Toba

Gambar 9 merupakan tampilan gambar untuk input ciri-ciri ulosBatak Toba.

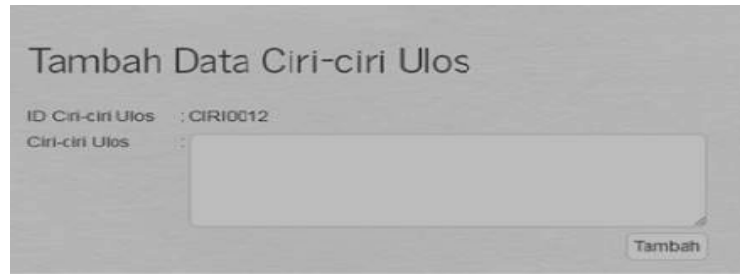

Gambar 9. Tampilan Input Petugas

\section{Tampilan Input Jenis Ulos Batak Toba}

Gambar 10 merupakan tampilan gambar untuk input jenis ulos Batak Toba. 


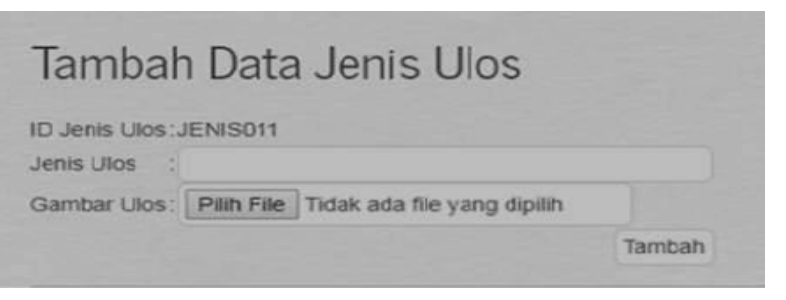

Gambar 10. Tampilan Input Jenis Ulos Batak Toba

\section{Tampilan Input Rule Ulos}

Gambar 11 merupakan tampilan gambar untuk input rule ulos. Sebelum penginputan data rule ulos, harus terlebih dahulu menginput jenis ulos dan ciri-ciri ulos.

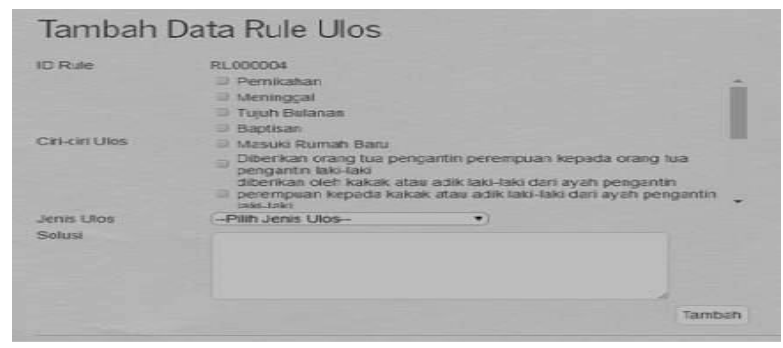

Gambar 11. Tampilan Input Rule Ulos

\section{Tampilan Input Konsultasi Jenis}

\section{Ulos Batak Toba Toba}

Gambar 12 merupakan tampilan gambar untuk input konsultasi jenis ulos Batak Toba. Untuk form penginputan Konsultasi, terdapat data yang wajib diisi yaitu nama, jenis alamat, telepon.

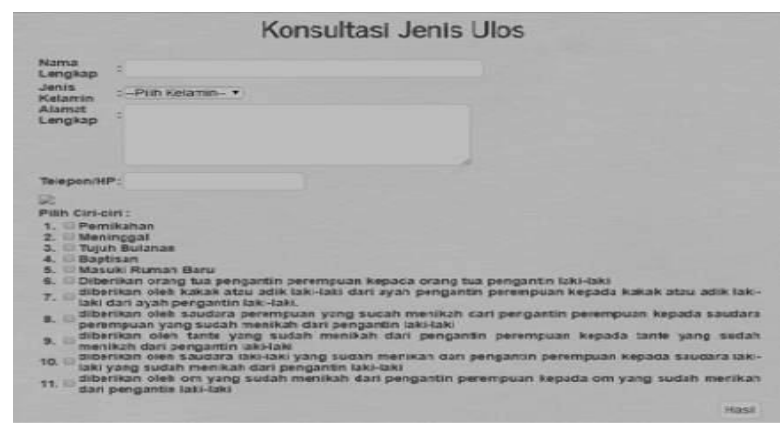

Gambar 12. Tampilan Input Konsultasi Jenis Ulos Batak Toba Toba

\section{Tampilan Halaman Utama}

Gambar 13 merupakan tampilan gambar untuk menu utama pengguna website ulos Batak Toba Toba.

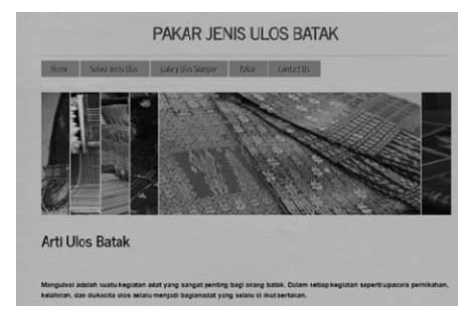

Gambar 13. Tampilan Halaman Utama

\section{Tampilan Halaman Utama Pakar}

Gambar 14 merupakan tampilan gambar untuk menu halaman utama pakar.

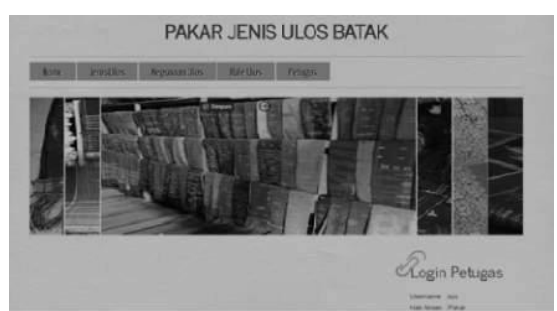

Gambar 14. Tampilan Halaman Utama Pakar

9. Tampilan Menu Jenis Ulos Batak Toba

Gambar 16 merupakan tampilan gambar untuk menu jenis ulos Batak Toba.

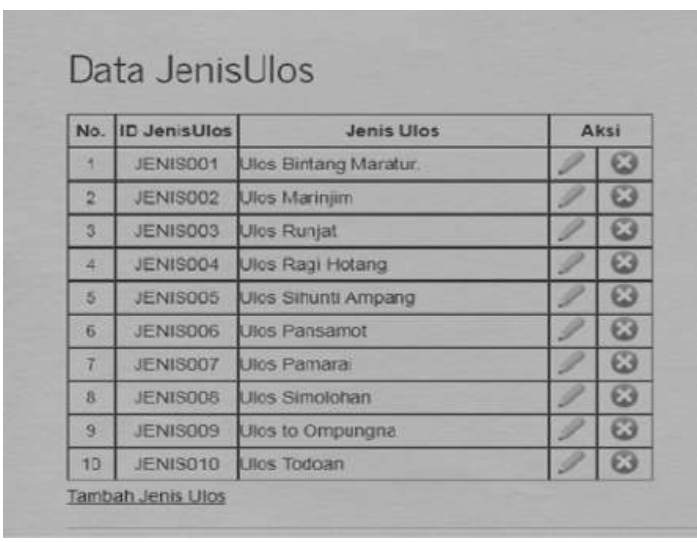

Gambar 16. Tampilan Jenis Ulos Batak Toba

\section{Tampilan Menu Tambah Ciri-ciri Ulos Batak Toba}


Gambar 17 merupakan tampilan gambar untuk tambah ciri-ciri ulos Batak Toba.

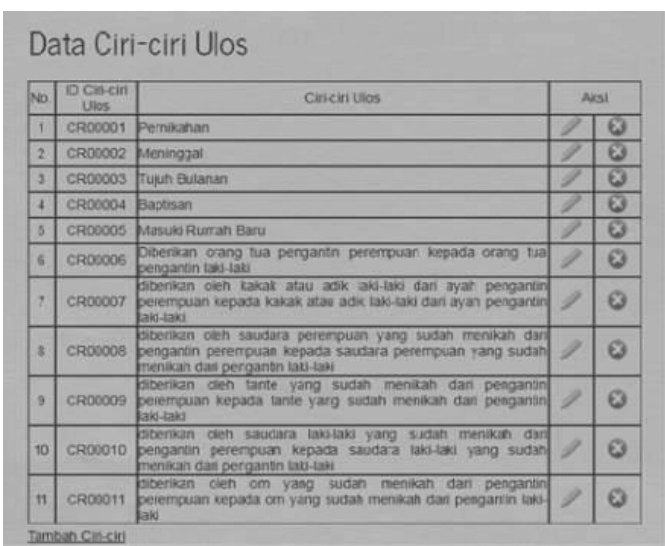

Gambar 17. Tampilan Menu Tambah Ciri- ciri Ulos Batak Toba

\section{Tampilan Menu Rule Ulos Batak}

\section{Toba}

Gambar 18 merupakan tampilan gambar untuk menu rule ulos Batak Toba.

\begin{tabular}{|c|c|c|c|c|}
\hline \multicolumn{5}{|c|}{ Data Rule Ulos } \\
\hline No. & ID Rule & ID Ciri-cin Ulos & $\begin{array}{c}\text { 10 Jenis } \\
\text { Ulos }\end{array}$ & Aksi \\
\hline \begin{tabular}{|l|l}
1 \\
\end{tabular} & 20000001 & CFOOOO1, CFOOOC2 CROOOC 3 , CROOOOA & JENISO01 & 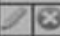 \\
\hline 2 & RL.000002 & CF00005,CF00006 & JENIS002 & $\bar{x}$ \\
\hline 3 & RL00000s & 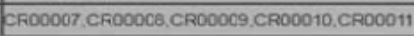 & JENIS003 & $\Phi$ \\
\hline Tar & bah Rule & & & \\
\hline
\end{tabular}

Gambar 18. Tampilan Menu Rulei Ulos Batak Toba

\section{Tampilan Menu Petugas}

Gambar 19 merupakan tampilan gambar untuk menu petugas.

\section{Data Petugas Sistem Pakar

\begin{tabular}{|c|c|c|c|c|c|c|c|}
\hline No & ID nerugas & Nana Lengkap. & Ketamm & Telicpon & uscrname & Nees & Mat \\
\hline 1 & PTGODO01 & ริ & sys & श्5 & sys & Paka & $\boldsymbol{x}$ \\
\hline 2 & PTGW0002 & Yolanda Rumapes & Peempuan & ber9379sr22 & $\begin{array}{l}\text { Yolanca } \\
\text { Rumagea }\end{array}$ & Adrin & 8 \\
\hline
\end{tabular}

Gambar 19. Tampilan Menu Petugas

\section{Tampilan Hasil Identifikasi Jenis Ulos Batak Toba}

Gambar 20 merupakan tampilan gambar untuk hasil identifikasi jenis ulos Batak Toba Toba. Form hasil identifikasi ini dapat dilihat setelah menginput data pengguna dan ciri-ciri ulos batal toba yang akan di cari.

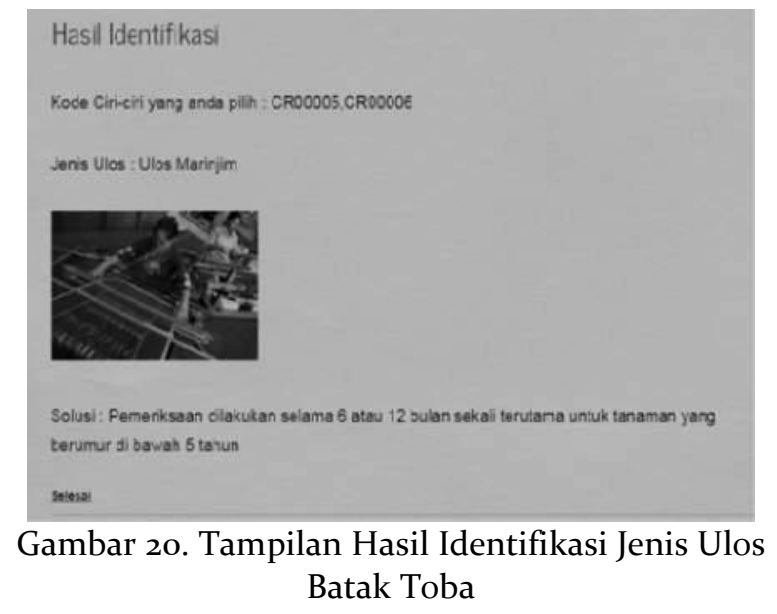

\section{SIMPULAN}

Adapun kesimpulan yang dibuat peneliti adalah sebagai berikut:

1. Hasil konsultasi berhasil dengan menampilkan jenis ulos yang digunakan dan juga solusi dan keterangan penggunaan ulos tersebut.

2. Aplikasi ini sangat membantu masyarakat batak untuk mengakses jenis ulos yang cocok digunakan oleh acara adatnya

Adapun saran yang dibuat peneliti adalah sebagai berikut: 
1. Diharapkan ada pengembangan dari sistem pakar identifikasi jenis ulos yang peneliti rancang sehingga dapat menciptakan sistem pakar yang lebih maju, dan dapat membuat data ciriciri ulos yang lebih spesifik pada masa yang akan datang.

\section{UCAPAN TERIMAKASIH}

Peneliti mengucapkan terima kasih kepada Direktorat Riset dan Pengabdian Masyarakat, Kementerian Riset, Teknologi, dan Pendidikan Tinggi yang telah mendanai penelitian ini sehingga penelitian ini berjalan dengan baik dan lancar.
Berbasis Web," Jurnal Teknika, Vol 6, No 2, pp 585-591, September (2014).

N. Sri. "Peranan Dinas Kebudayaan dan Pariwisata dalam Pengembangan BudayaDaerah di Kabupaten Malinau," E-Journal Pemerintah Integrative, Vol 3, No 4, pp 570-582,2015.

D.P. Fransiska."Makna Simbolik Upacara Mangongkal Holi Bagi Masyarakat Batak Toba Tobadi Desa Simanindo Kecamatan Simanindo Kabupaten Samosir Provinsi Sumatera Utara," Jurnal Online Mahasiswa Fisip, Vol 2, No 2, pp 1-15, Oktober 2015.

C. Agustina. "Makna dan Fungsi Ulos Dalam Adat Masyarakat Batak Toba Toba di Desa Talang Mandi Kecamatan Mandau Kabupaten Bengkalis," Jurnal Online Mahasiswa Fisip, Vol 3, No 1, pp 1-15, Februari 2016.

M.S. Destien\& H. Dasrun. "Pola Komunikasi pada Prosesi Mangulosi dalam Pernikahan Budaya Adat Batak Toba Toba," Jurnal Ilmu Komunikasi (J-IKA), Vol 2, No 1, pp 2331, April

2015.

T. Sutojo, Edy Mulyanto\& Vincen Suhartono.Kecerdasan Buatan. Jakarta, Indonesia: Penerbit Andi Offset, 2010.

Wijaya, Edi. "Analisis Penggunaan Algoritma Breadth First Search dalam Konsep Artificial Intellegencia, Jurnal TIME, Vol 2, No 2, pp 18-26",2013.

Abram, Gidean., et al. "Sistem Pakar untuk Penyakit Anak menggunakan Metode Forward Chaining, Jurnal Infra 3 (2), pp 18pp. 24",2015.

\section{DAFTAR PUSTAKA}

A. Zulfian. "Aplikasi Jaringan Saraf Tiruan untuk Pengenalan Pola Pembukaan Permainan Catur," Jurnal Saintikom, Vol 10, No 1, Januari (2011).

D. Muhammad. "Pengembangan Sistem Pakar dalam Membangun Suatu Aplikasi," Jurnal Saintikom, Vol 10, No 3, pp 119-205, September (2011).

Daniel \& Virginia, G."Implementasi Sistem Pakar untuk Mendiagnosis Penyakit dengan Gejala Demam Menggunakan Metode Certainty Factor," Jurnal Informatika, Vol 6, Nomor 1, pp 25-36,April (2010).

L. Hersatoto. "Merancang dan Membuat Sistem Pakar," Jurnal Teknologi Informasi DINAMIK, Vol 8, No2, pp

115-124, Juli 2008.

M. Siti. "Diagnosa Penyakit Tanaman Hias Menggunakan Metode Certainty Factor 